\title{
Update on Kaposi sarcoma-associated herpesvirus (KSHV or HHV8) - review
}

\author{
NICOLETA IFTODE ${ }^{2}$, MIHAELA ANDREEA RĂDULESCU ${ }^{1,2}$, ȘTEFAN SORIN ARAMĂ $\breve{1}^{1,2}$, VICTORIA ARAMĂ $\breve{1}^{1,2}$ \\ 1 “Carol Davila" University of Medicine and Pharmacy, Bucharest, Romania \\ 2 "Prof. Dr. Matei Balș” National Institute for Infectious Diseases, Bucharest, Romania
}

All authors have equally contributed to this work.

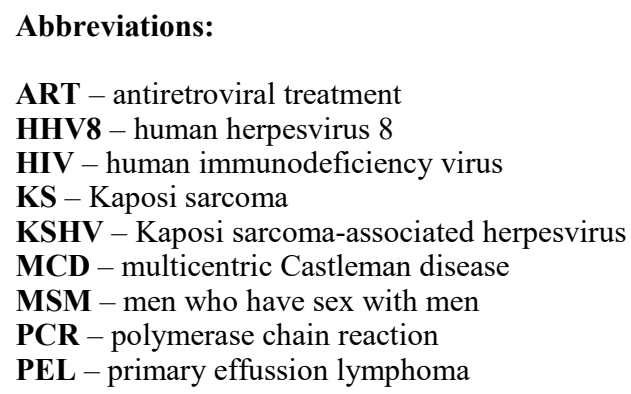

Human herpesvirus 8 (HHV8), also known as Kaposi sarcoma-associated herpesvirus (KSHV), is one of the few pathogens recognized as direct carcinogen, being involved in the pathogenesis of Kaposi sarcoma, primary effusion lymphoma and multicentric Castleman disease. KSHV is a relatively recently discovered virus, with still limited possibilities for diagnosis and treatment. Therefore, ongoing studies are trying to answer the main issues related to the management of KSHV infection and its associated diseases. This review updates the current knowledge of the KSHV infection, discussing aspects related to epidemiology, virological features, clinical manifestations, diagnosis and treatment.

Key words: Kaposi sarcoma-associated herpesvirus, KSHV, Kaposi sarcoma, primary effusion lymphoma, multicentric Castleman disease.

\section{What is new/what is important}

Kaposi sarcoma-associated herpesvirus (KSHV) was first described in 1994 in relation to Kaposi sarcoma. Later on KSHV was associated to other malignancies: primary effusion lymphoma and multicentric Castleman disease. KSHV inflammatory cytokine syndrome was recently described in HIV co-infected patients.

KSHV seroprevalence varies in diferent geographical areas, and is likely underestimated, since there are no standardized serological tests for the diagnosis of this infection.

Since most cases of KSHV-associated malignancies occur in HIV-infected and other immunosupressed patients, clinicians should be aware of these conditions and even screen for KSHV in high-risk patients.

So far there are no effective antivirals against KSHV.

\section{INTRODUCTION}

Human herpesvirus 8, also known as Kaposi sarcoma-associated herpesvirus (KSHV), is one of the few pathogens recognized as direct carcinogen, causing over 40,000 cases of cancer and 20,000 deaths worldwide each year [1].

$\mathrm{KSHV}$ is a relatively recently discovered virus. It was first isolated from Kaposi sarcoma lesions in 1994, hence its name [2]. In addition to Kaposi sarcoma, KSHV causes two lymphoproliferative disorders - primary effusion lymphoma and multicentric Castleman disease [3]. There are also several findings indicating the involvement of KSHV in other chronic or neoplastic diseases [4].

Because the seroprevalence of KSHV is insufficiently studied in the general population and access to the laboratory diagnosis of this infection is relatively limited, the involvement of KSHV in human pathology is incompletely elucidated. 


\section{EPIDEMIOLOGY OF KSHV INFECTION}

Unlike other herpesviruses that are ubiquitous, the seroprevalence of KSHV is significantly lower and varies from one geographic area to another (Figure 1) [5]. There are endemic areas in Africa and the Middle East where the seroprevalence of KSHV infection in the general population is between $14-86 \%$, the highest rates of seroprevalence being found in the so-called "Kaposi sarcoma belt" from
Sub-Saharan Africa [6]. A moderate seroprevalence of KSHV infection is reported in Southern Europe, being estimated between 10-30\% [4]. In the USA and Northern Europe the seroprevalence of KSHV infection in the general population is low, being estimated at around 6\% [7]. In these regions with low seroprevalence, the highest values are recorded in HIV-positive men having sex with men (MSM) (30-60\%) and HIV-negative MSM (20-30\%) [4]. Regarding Romania, there are currently no data on KSHV seroprevalence.

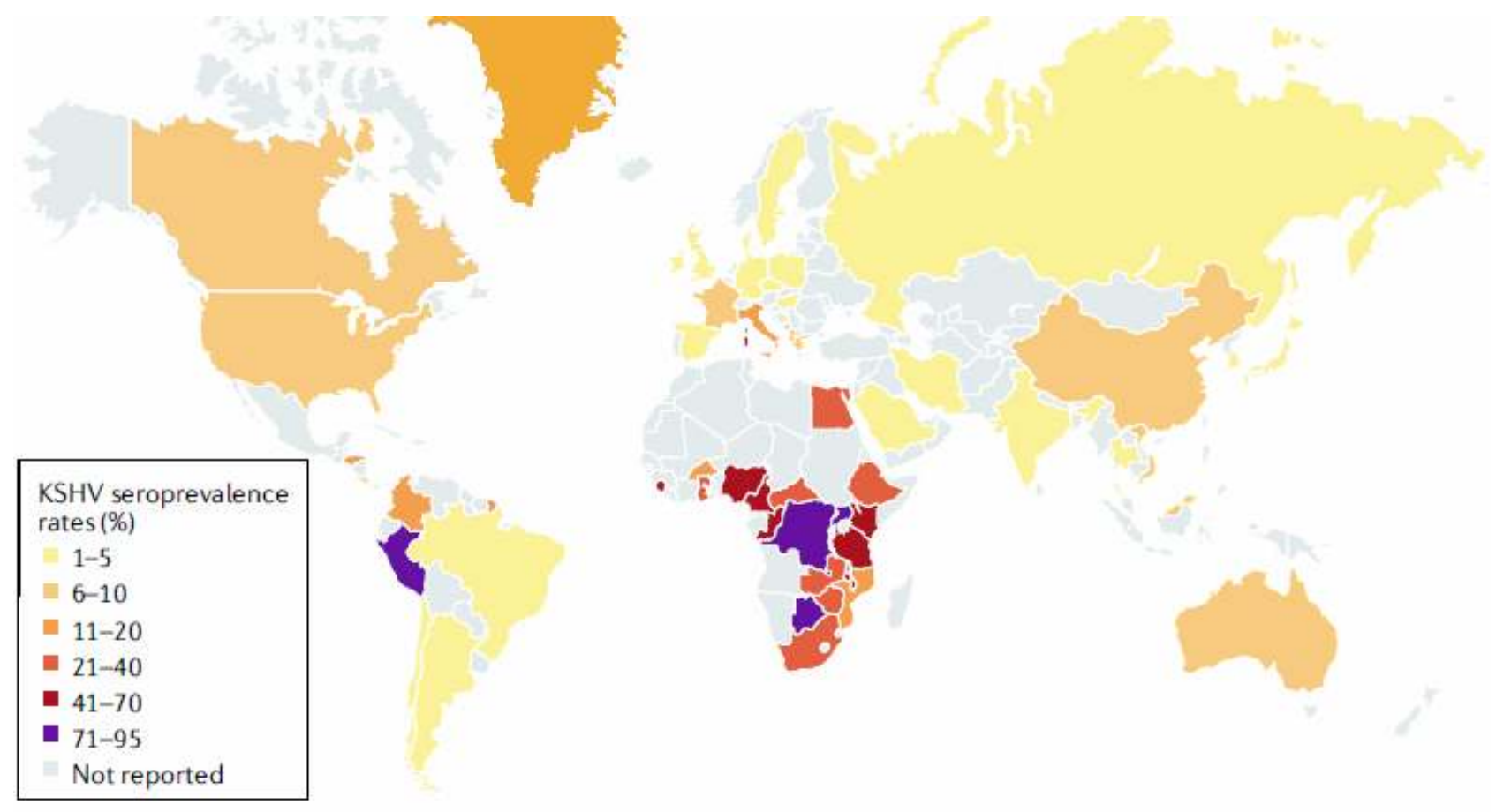

Figure 1. Worldwide KSHV seroprevalence (cumulative data from several studies conducted between 1998-2015). Figure modified from Cesarman et al. [9] and Mesri et al. [10].

It should be noted that different and nonstandardized serological diagnostic techniques are used in the research conducted till now. In addition, a low titer of anti-KSHV antibodies may not be detected by currently available tests, which is why the seroprevalence of KSHV infection may be underestimated [8].

$\mathrm{KSHV}$ is excreted mainly in the saliva and semen of the infected patient (Table 1). In endemic countries for KSHV infection, there is an increased seroprevalence in children, which suggests a possible horizontal transmission through saliva. In contrast, in countries with low seroprevalence, KSHV infection is rare in children. In these areas the transmission is probably mainly sexual, the risk of infection correlating with the number of sex partners and a history of sexually transmitted diseases [11]. Regarding blood transmission, it seems to be more common among injecting drug users, although there are studies that do not confirm this supposition. Transmission through blood transfusions appears to be very low in lowprevalence countries, but it has been reported in endemic countries [5]. In addition, transmission by organ transplantation is considered, cases of rapidly progressing KS being reported in transplant recipients [12]. All these routes of transmission are still speculative and the pattern of transmission of KSHV infection remains unclear [13]. 
Table 1

Presence of KSHV in potentially infectious body fluids (\%). Modified from Martin et al. [14].

\begin{tabular}{|c|c|c|c|}
\hline \multirow{2}{*}{} & \multicolumn{2}{|c|}{ KSHV +} & KS,- HIV - \\
\cline { 2 - 4 } & KS + & KS -, HIV + & $10-20$ \\
\hline Saliva & 22 & $20-35$ & $<1$ \\
\hline Semen & 6 & $<1$ & 1 \\
\hline Feces & NA & 1 & $<1$ \\
\hline
\end{tabular}

KSHV - Human herpesvirus 8, KS - Kaposi sarcoma, HIV - Human immunodeficiency virus, „,” - presence of infection/disease, ,-" - absence of infection/disease, NA - not available.

\section{VIROLOGY, IMMUNOLOGY AND PATHOGENESIS OF KSHV}

KSHV belongs to the subfamily Gammaherpesvirinae, the genus Rhadinovirus. It is most closely related to the Epstein-Barr virus, being a lymphotropic and oncogenic virus [4].

KSHV infects both B lymphocyte and $\mathrm{T}$ lymphocyte, monocytes, endothelial cells and keratinocytes. Of these, the main reservoir of latent $\mathrm{KSHV}$ is thought to be the CD19-positive B lymphocyte. Like any herpesvirus, KSHV has both latent and lytic life cycles. After entering the target cell, the virus remains latent temporarily or for the rest of the individual's life, without causing a host immune response against infected cells [4]. The immune response is attenuated mainly by the synthesis of viral proteins with a structure similar to cellular proteins involved in the antiviral response. These homologues inhibit the synthesis and antiviral action of interferon, inhibit apoptosis and stimulate the mechanisms of oncogenesis [15].

The determinants for entering from latency into the lytic phase (viral replication) are incompletely known. Viral co-infections, especially HIV infection, appear to play a role in triggering KSHV replication, both by direct activation of toll-like receptors (TLRs) and by induction of inflammatory cytokines [16].

Regarding the oncogenic role of KSHV, two mechanisms are described [4]. The classical mechanism of neoplastic transformation by viral proto-oncogenes (v-cyclin D or v-BCL-1) is questioned especially regarding the pathogenesis of Kaposi sarcoma [4]. In contrast, an important role is attributed to viral proteins and inflammatory cytokines induced by KSHV. Among the most studied are viral interleukin 6 (v-IL6), viral G protein-coupled receptor (v-GPCR), viral interferon regulatory factor-1 (v-IRF-1) and viral macrophage inflammatory protein (v-MIP) $[15,17]$. Because paradoxically neither latent KSHV nor lytic KSHV can cause tumor transformation of the cells, the so-called "paracrine oncogenesis" hypothesis has been proposed. This involves the release of molecules from lytically infected cells, which will stimulate latently infected cells by paracrine signaling. This will lead to ignoring the normal signals of cell cycle regulation, inhibition of apoptosis, uncontrolled proliferation, angiogenesis and evasion of the immune system [17]. An interesting hypothesis related to these viral proteins is that v-MIP would bind to the type $3 \mathrm{CC}$ chemokine receptor (CCR3) required for HIV to enter glial cells. This would prevent HIV from entering the cells, reducing the risk of AIDS-associated dementia. However, studies are not strong enough to support this effect [18].

It should be noted that KSHV infection can exert its oncogenic effect only in the presence of co-factors, such as genetic susceptibility and immunosuppression [17]. Immune status has a unanimously accepted role in the pathogenesis of KSHV-associated diseases. Arguments in this regard are the increased incidence of Kaposi sarcoma (KS) in HIV and transplant patients, as well as the regression of KS lesions under antiretroviral treatment or after lowering the doses of immunosuppressive therapy [19]. T lymphocytes are mainly involved in the antiviral immune response, but also natural killer cells (NK), as well as neutralizing antibodies [20].

Of particular importance is the involvement of neutralizing antibodies, as research in this direction has paved the way for a possible KSHV vaccine. Studies have shown that the titer of KSHV antibodies in patients with KS was significantly lower compared to that of patients infected with KSHV but without KS lesions [20]. Based on this findings, researchers began designing a vaccine. They used virus-like molecules composed of several key KSHV envelope glycoproteins. These molecules inoculated in rabbits were able to generate moderate titers of neutralizing antibodies, which subsequently prevented in vitro KSHV infection of epithelial, endothelial cells and $\mathrm{B}$ lymphocytes. Ongoing studies are trying to establish the configuration of the molecule that could be effective in vivo in preventing KSHV infection [21]. 


\section{CLINICAL FEATURES OF KSHV INFECTION}

Like any herpesvirus, KSHV causes a primary infection following initial entry to the host. After that, KSHV remains dormant in target cells, but can resume replication, especially under conditions of immunosuppression. The clinical manifestations in reactivations are different from those of the primary infection [22].

Primary KSHV infection is often asymptomatic. It can be documented only by highlighting KSHV antibody seroconversion (positive KSHV antibody test in an individual who previously had a negative KSHV antibody test). Symptomatic primary KSHV infection is rarely reported, being described only in children, MSM and immunocompromised subjects [23].

In immunocompetent children, primary KSHV infection may present as a febrile maculo-papular rash [23]. Fever syndromes with lymphadenopathy, splenomegaly and arthralgias have been reported in immunocompromised individuals. KSHV seroconversion was also associated with the appearance of disseminated KS lesions and bone marrow failure in two patients who received a kidney transplant from the same KSHV-seropositive donor [24]. In addition, cases of lymphadenopathy, localized rash, diarrhea, and asthenia have been reported in HIV-negative MSM [25].

\section{KAPOSI SARCOMA}

Kaposi sarcoma (KS) is the most common KSHV-associated disease. It was first described in 1872 by Moritz Kaposi and was initially considered a rare, slowly evolving condition. Then, in the early 1980s, with the outbreak of the HIV/AIDS epidemic, the number of KS cases and their severity increased considerably. Although the incidence of KS has decreased significantly after the introduction of antiretroviral therapy, it remains the leading neoplasm associated with HIV/AIDS, occurring in $20 \%$ of patients [4].

$\mathrm{KS}$ is an atypical malignant tumor, which is characterized mainly by angioproliferative inflammatory changes and less by typical sarcoma lesions [4].

Cutaneous KS is the most common form of $\mathrm{KS}$ and is characterized by the presence of pinkpurple, angiomatous, rounded, well-defined, infiltrated maculopapules, which do not disappear under pressure and do not bleed on palpation. These lesions are painless, non-itchy, have different sizes $(0.5-2 \mathrm{~cm})$ and are located symmetrically along the lines of skin tension (Figure 2). Initially, pink maculopapules appear, which infiltrate progressively, turning into purplish nodules or plaques. In black patients, KS lesions may appear dark brown or black. Commonly affected areas are the face (especially the periorbital, perioronasal and retroauricular area), the upper half of the trunk and the extremities of the lower limbs (plantar, periungual). At the neck and trunk, the KS plaques have a linear shape, being oriented downwards and towards the midline, similar to the fir branches. This arrangement follows the skin drainage lines known as the Langer lines (Figure 2, D) [22].

Mucosal KS is also common, affecting the conjunctival, oropharyngeal (hard palate, gums, tonsils) and genital mucosa (Figure 3) [22]. Up to $60 \%$ of patients with HIV/AIDS-associated KS may have lesions in oral cavity (Figure 3, A), which is usually an unfavorable prognostic factor [26]. In $20 \%$ of patients the oral mucosa may be the initial site of KS. Moreover, KS located in the oral cavity may sometimes be the first sign of an undiagnosed HIV infection. Although the lesions may remain strictly localized in the oral cavity, possible extension to the respiratory and digestive tract should be considered. This extension occurs in about $70 \%$ of patients with oral lesions, but is often subclinical and underdiagnosed. The appearance of hemoptysis, hematemesis or melena, as well as other symptoms of the respiratory or digestive tract may be arguments for visceral spread [27]. Not least, lymph node involvement, especially reported in endemic regions, should be mentioned [28].

KS was classified into four clinicalepidemiological forms: classic KS, endemic KS, epidemic KS (or AIDS-associated KS) and iatrogenic KS. A fifth form called non-epidemic KS has recently been added [29].

- Classic KS was the first form of KS described, usually affecting elderly men of Ashkenazi Jewish and Mediterranean origin [30]. The lesions are generally located in the lower limbs, are painless and have a benign evolution [5].

- Endemic $K S$ is described in Equatorial Africa, especially in children. It is an aggressive form, with a severe prognosis and rapid evolution towards death [28]. It commonly involves lymph nodes and significant local edema may occur. In these regions, $\mathrm{KS}$ is one of the main neoplasms, representing a real public health problem [5].

- Epidemic KS (HIV/AIDS-associated KS), although less frequently reported after the introduction of antiretroviral treatment, remains the most common HIV-associated malignancy, being also an AIDSdefining condition [4]. It should be noted that one third 
of patients who develop KS have well-controlled HIV infection with low viral load and high CD4 cell count $\left(>200\right.$ cells $\left./ \mathrm{mm}^{3}\right)$. As the majority of patients in this subcategory are elderly, it is estimated that the number of cases may increase as the life expectancy of HIV patients increases and close monitoring is recommended [31].

- Iatrogenic $K S$ occurs in transplant patients and/or in patients undergoing immunosuppressive therapy. Most cases are described in kidney transplant patients. The highest incidence is found in the countries where classic KS and endemic KS are often reported.
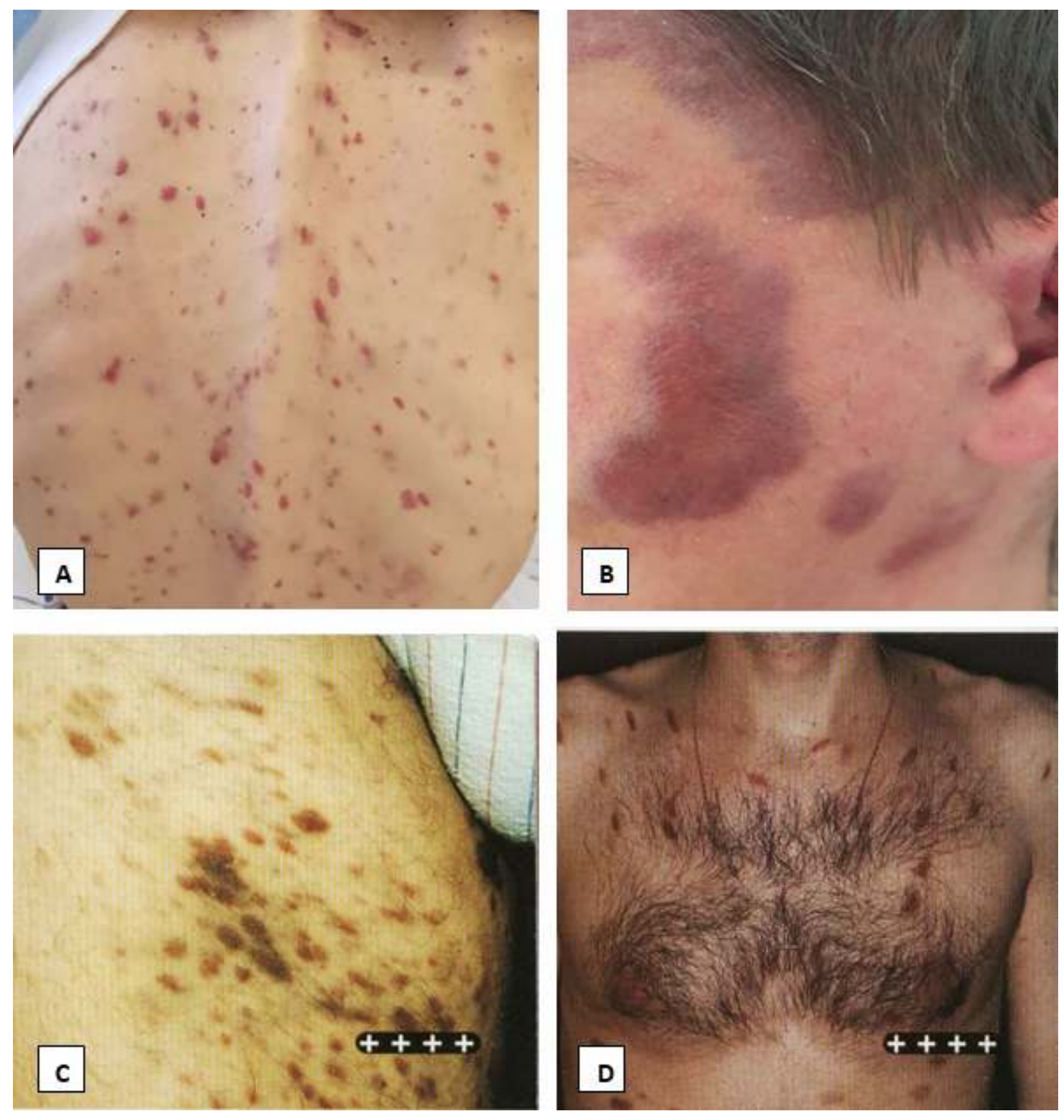

Figure 2. Kaposi sarcoma - disseminated cutaneous involvement. A, B - Images from the collection of the Adults 3 Departament from "Prof. Dr. Matei Balş" National Institute for Infectious Diseases, Bucharest. C, D - Courtesy of Aramă et al. [22].

$\mathrm{KS}$ is the most common post-transplant neoplasm in these regions [32]. The lesions usually regress after dose reduction or cessation of the immunosuppressive therapy [19]. KS affects $0.5 \%$ of transplant patients and occurs 10-22 months post-transplant [22].

- Non-epidemic KS is a recently introduced category, which affects HIV-negative MSM. This form of KS has a better prognosis, as lesions are often limited [29].

It should be noted that although most cases of KS fit into one of these 5 categories, atypical cases of KS have also been reported [33].

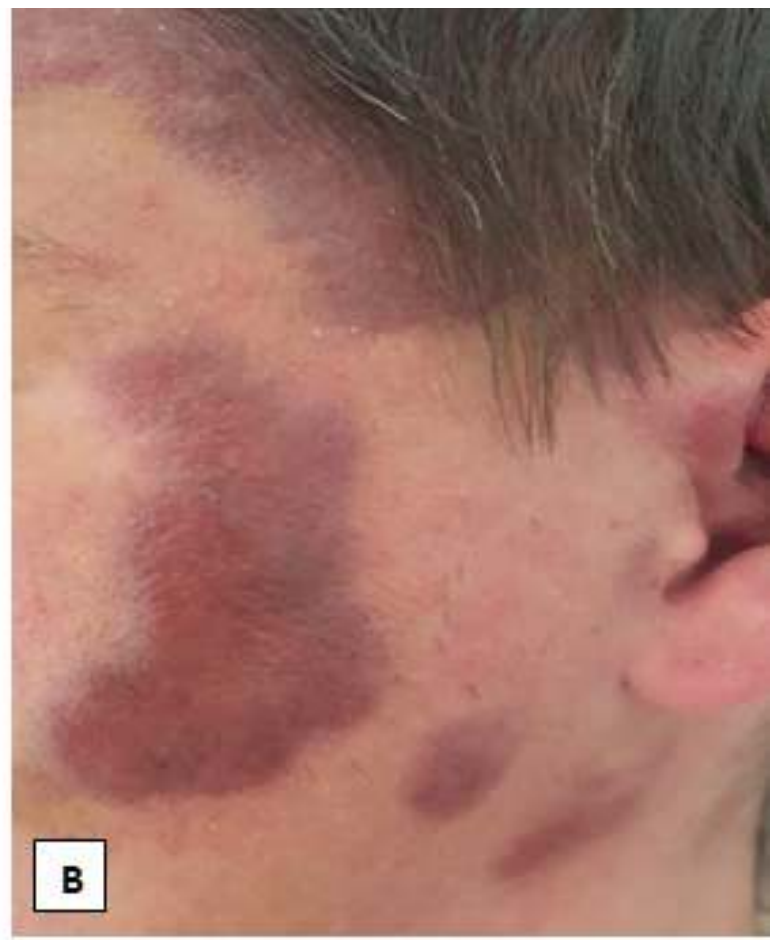




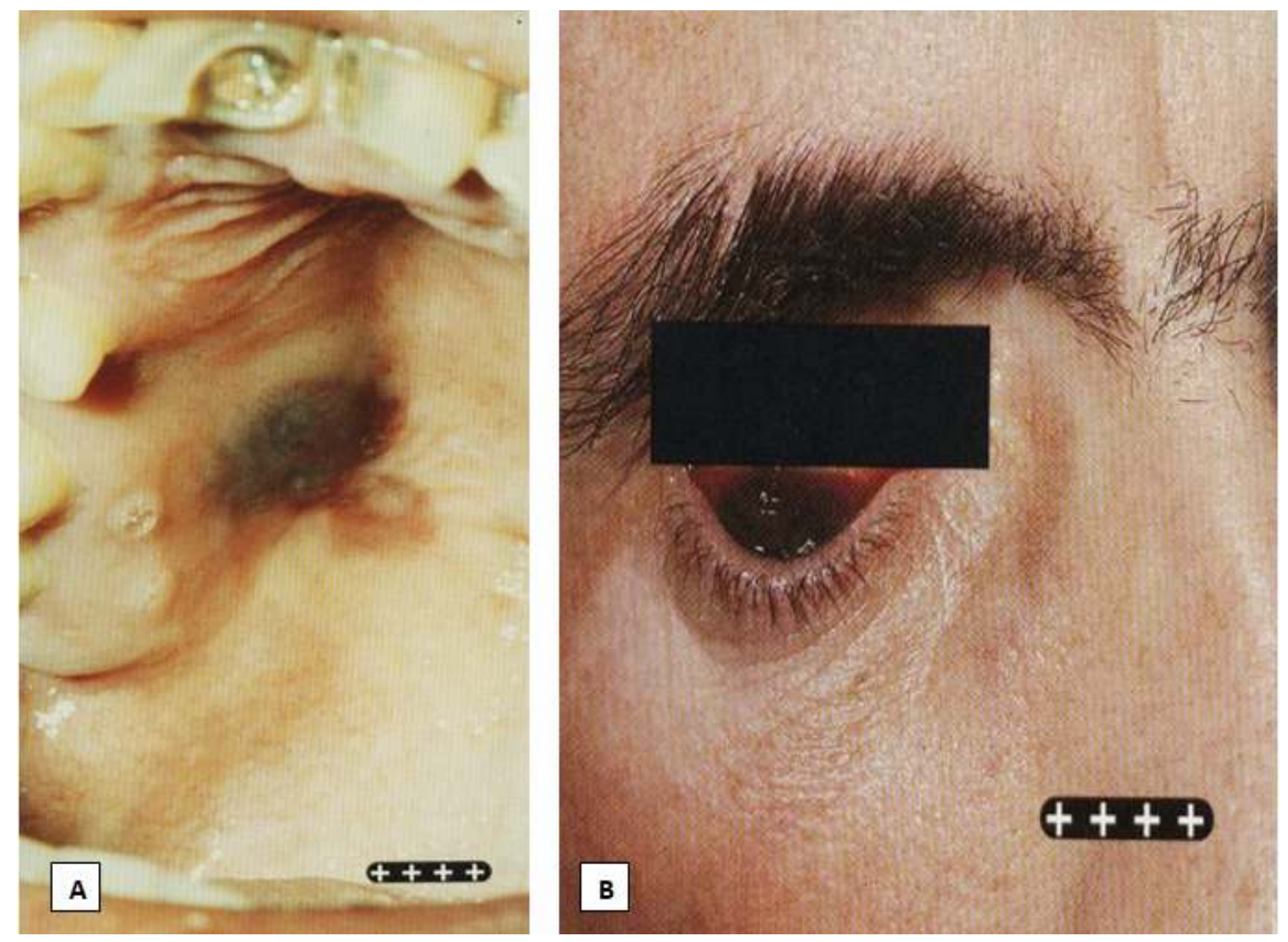

Figure 3. Kaposi sarcoma - mucosal involvement. A - Kaposi sarcoma of the hard palate. B - Conjunctival Kaposi Sarcoma. Courtesy of Aramă et al. [22].

\section{PRIMARY EFFUSSION LYMPHOMA}

Primary effusion lymphoma (PEL) is a rare and aggressive form of non-Hodgkin lymphoma that is characterized by the appearance of malignant fluid into the serous cavities without detecting tumor masses [3]. An interesting aspect is that tumor cells in PEL are frequently co-infected with Epstein-Barr Virus. Recent studies show that the two viruses potentiate each other in the process of oncogenesis [34].

The symptoms are caused by fluid accumulation, the patient usually presenting for dyspnea, when the pleura or pericardium is affected, or for ascites when the peritoneum is involved. Nonspecific symptoms may also occur, such as fever and altered general condition [3].

PEL represents approximately $4 \%$ of AIDSassociated lymphomas and is rarely seen in HIVnegative patients. The average survival time is 10 months [5].

\section{MULTICENTRIC CASTLEMAN DISEASE}

Multicentric Castleman disease (MCD) is one of the clinical forms of Castleman disease, being a multifocal B-cell lymphoproliferative disorder, characterized mainly by generalized lymph node hypertrophy and systemic symptoms (fever, night sweats) secondary to excessive production of IL-6. Hepatosplenomegaly and respiratory dysfunction may also be associated. In severe forms MCD may mimic sepsis, with hypotension, pancytopenia, and multiple organ failure. The evolution of MCD is characterized by exacerbations and relapses. A relapse may have as a pathophysiological substrate the onset of a so-called "cytokine storm" or a macrophage activation syndrome [5]. MCD is not a malignancy per se, but is associated in $32 \%$ of cases with the onset of neoplasms, including KS and PEL [35]. The average survival time is 1 year [5].

KSHV infection is involved in almost all cases of MCD associated with HIV infection and in about $40 \%$ of cases of MCD in HIV-negative patients [36]. Being a very rare and complex pathology, MCD is still insufficiently known and probably underdiagnosed [5].

\section{KSHV INFLAMMATORY CYTOKINE SYNDROME}

KSHV inflammatory cytokine syndrome is a recently described clinical feature in HIV and KSHV 
co-infected patients. It is characterized by MCD-like symptoms, high KSHV viral load and high IL-6 titer, but without pathological changes suggestive of MCD [5].

In addition to these pathologies in which the involvement of KSHV has been proven, there are a number of other chronic diseases in which the suspicion of a possible association with KSHV infection has been raised. This category includes sarcoidosis, idiopathic pulmonary hypertension and pemphigus vulgaris, but there is insufficient evidence to confirm the involvement of KSHV in the pathogenesis of these diseases [4]. On the other hand, there are sufficient arguments to rule out the involvement of KSHV in the pathogenesis of multiple myeloma [37]. In addition, there are recent studies indicating that KSHV infection could contribute to oxidative stress involved in the pathogenesis of type 2 diabetes [38].

\section{DIAGNOSIS OF KSHV INFECTION AND KSHV-ASSOCIATED DISEASES}

The diagnosis of KSHV infection has not yet entered current clinical practice, as access to laboratory techniques that confirm this infection is still limited. To date, there are no standardized serological tests with adequate sensitivity and specificity for the diagnosis of KSHV infection. In addition, KSHV is difficult to isolate on cell cultures, and molecular diagnostic methods for viral DNA detection (PCR) are expensive and of limited utility [8]. This limitation is due to the fact that the virus remains dormant for long periods, with occasional reactivations, which is why only $10 \%$ of asymptomatic patients infected with KSHV will have positive PCR in the peripheral blood. However, quantitative determination of viral load is useful in HIV-positive patients, who may be diagnosed with a possible KSHV inflammatory cytokine syndrome, as well as in transplant patients [5].

Regarding the diagnosis of Kaposi sarcoma, the clinical surveillance of high-risk patients and the recognition of characteristic lesions are essential. The examination of the oral cavity should not be omitted, as in a significant percentage of patients it may be the site of onset or even the only location of KS. With regard to post-transplant KS, attention should be paid to apparently infected post-operative granulomas with delayed healing, as they may hide KS lesions. However, the clinical appearance is not enough for the diagnosis of KS. For this, a biopsy of the lesions must be performed, followed by histopathological and possibly immunohistochemical analysis. When a mucosal $\mathrm{KS}$ is diagnosed, it is necessary to complete the investigations with upper and lower digestive endoscopy and chest and abdominal computed tomography, in order to exclude the visceral involvement of the KS. Last but not least, it is important to look for a possible undiagnosed HIV infection [22].

Regarding KSHV-associated lymphoproliferative disorders, the diagnosis may be suggested by the association of non-specific clinical manifestations (polyadenopathies, fever, asthenia) with certain laboratory changes, such as high levels of LDH and beta2-microglobulin [22]. However, a definitive diagnosis requires histopathological examination. Immunohistochemical staining with anti-LANA (latency associated nuclear antigen) antibodies or PCR-based techniques can be used to identify KSHV DNA in tumor tissues. It should be noted that the identification of KSHV DNA in peripheral blood does not have a well-defined role in the diagnosis of KS, PEL and MCD [13].

\section{TREATMENT OF KSHV INFECTION AND KSHV-ASSOCIATED DISEASES}

To date, no antiviral treatment has been shown to be truly effective in vivo and in vitro on KSHV. The lack of efficacy can be explained by the fact that most cells are infected with the virus in the latent phase, while the existing antivirals target the viral replication phase. Based on this observation, new research aims to associate an antiviral treatment with one that induces viral reactivation. This therapeutic approach is known as "lytic induction therapy" [39].

Recent studies have shown an important role of histamine in the reactivation of KSHV. Therefore, another approach involves the development of new antiviral agents that target histamine receptors or its signaling pathways, thereby preventing the virus from entering the lytic phase [40].

The treatment of Kaposi sarcoma depends on the clinical form and the extent of the lesions. In AIDS-associated KS, the treatment of localized skin lesions involves in the first stage the initiation or optimization of antiretroviral therapy (ART), which may lead to regression of the lesions [41]. Local treatment consisting of surgical excision, intralesional chemotherapy or local radiotherapy may be an option for localized lesions [42]. In disseminated skin lesions and visceral involvement, the association of ART with systemic chemotherapy is indicated. Liposomal doxorubicin is the first-line treatment. For posttransplant KS treatment primarily involves dose reduction or discontinuation of immunosuppressive therapy $[13,42]$. 
The treatment of primary effusion lymphoma consists in the combination of ART (in HIV-positive patients) and chemotherapy. Being a relatively rare pathology, there is no standardized treatment [13].

The treatment of multicentric Castleman disease is not standardized either, given the low incidence of this condition. Chemotherapeutic agents have not been shown to be effective in disease control, but have led to an improvement in symptoms [43]. Rituximab may have a significant regression effect of MCD, but has the disadvantage that one third of patients develop either a new KS or an exacerbation of a pre-existing KS [13, 43].

In the management of all these pathologies, but especially in KS, it is important to consider the immune reconstitution inflammatory syndrome (IRIS), which consists in the paradoxical aggravation of the lesions after the initiation of ART. IRIS treatment consists of systemic chemotherapy. It should be noted that the use of corticosteroid therapy is not recommended in IRIS or in the treatment of KSHV-associated diseases, as it may cause the development of KS or exacerbation of pre-existing KS lesions with the possible occurrence of lifethreatening complications [13].

\section{PREVENTION OF KSHV INFECTION AND KSHV-ASSOCIATED DISEASES}

Given that the route of KSHV transmission is still speculative, there is currently no recommendation to prevent exposure. Also, there is still no proven effective and safe vaccine. Regarding the prevention of KS, PEL and MCD, early initiation of ART in HIV-infected patients is the most effective prevention measure [13].

\section{CONCLUSIONS}

KSHV is a relatively recently discovered virus, and although significant progress has been made in its description, there are still many research directions. Probably the main way that would allow a better diagnosis and description of KSHV infection would be the development of standardized serological tests, with high sensitivity and specificity. In addition, the significant mortality of KSHV-associated diseases emphasizes the need to identify effective therapies in terms of survival. On the other hand, the emergence of an effective vaccine would be the optimal way to manage KSHV infection.

Virusul herpetic uman 8, cunoscut şi sub denumirea de herpesvirusul asociat sarcomului Kaposi (KSHV), este unul dintre virusurile cu rol oncogen dovedit, fiind implicat în patogenia sarcomului Kaposi, a limfomului primar al cavităţilor şi a bolii Castleman multicentrice. KSHV este un virus relativ nou descoperit, având posibilităţi încă limitate de diagnostic şi tratament. Astfel, se află în desfăşurare studii care încearcă să răspundă la principalele probleme legate de managementul infecţiei cu KSHV şi al bolilor asociate. Acest articol actualizează datele din literatura de specialitate cu privire la infecţia cu KSHV, aducând în discuţie aspecte ce ţin de epidemiologie, particularităţi virusologice, manifestări clinice, diagnostic şi tratament.

Correspondence to: Nicoleta Iftode, M.D, "Prof. Dr. Matei Balş” National Institute for Infectious Diseases - Calistrat Grozovici street, no 1, sector 2, 021105, Bucharest, Romania

Telephone: 0744267734

E-mail: nicoleta.iftode@yahoo.com

Conflict of interest disclosure: The authors declare that there are not conflicts of interest.

\section{REFERENCES}

1. BRAY F, FERLAY J, SOERJOMATARAM I, SIEGEL RL, TORRE LA, JEMAL A. Global cancer statistics 2018: GLOBOCAN estimates of incidence and mortality worldwide for 36 cancers in 185 countries. CA Cancer J Clin 2018; 68(6): 394-424.

2. CHANG Y, CESARMAN E, PESSIN MS, et al. Identification of herpesvirus-like DNA sequences in AIDS-associated Kaposi's sarcoma. Science. 1994; 266(5192): 1865-9.

3. CALABRO ML, SARID R. Human Herpesvirus 8 and Lymphoproliferative Disorders. Mediterr J Hematol Infect Dis 2018; 10(1): e2018061. 
4. ARVIN A, CAMPIDELLI-FIUME G, MOCARSKI E, MOORE PS, ROIZMAN B, WHITLEY R, YAMANISHI K. Human Herpesviruses: Biology, Therapy and Immunoprophylaxis. Cambridge University Press, Cambridge, 2007: 341-903.

5. LABO N, WHITBY D. Kaposi's Sarcoma-Associated Herpesvirus: Epidemiology and Clinical Features of Related Cancer. In: Viruses and Human Cancer. Springer Science+Business Media, New York, 2014: 323-340.

6. DEDICOAT M, NEWTON R. Review of the distribution of Kaposi's sarcoma-associated herpesvirus (KSHV) in Africa in relation to the incidence of Kaposi's sarcoma. Br J Cancer. 2003; 88(1): 1-3.

7. ENGELS EA, ATKINSON JO, GRAUBARD BI, MCQUILLAN GM, GAMACHE C, MBISA G,COHN S, WHITBY D, GOEDERT JJ. Risk factors for human herpesvirus 8 infection among adults in the United States and evidence for sexual transmission. J Infect Dis. 2007; 196(2): 199-207.

8. TEDESCHI R, DILLNER J, PAOLI P. Laboratory Diagnosis of Human Herpesvirus 8 Infection in Humans. Eur J Clin Microbiol Infect Dis. 2002; 21(12): 831-844.

9. CESARMAN E, DAMANIA B, KROWN SE, MARTIN J, BOWER M, WHITBY D. Kaposi sarcoma. Nat Rev Dis Primers. 2019; 5(1): 9.

10. MESRI EA, CESARMAN E, BOSHOFF C. Kaposi's sarcoma and its associated herpesvirus. Nat Rev Cancer. 2010; 10(10): 707-719.

11. MARTIN JN, GANEM DE, OSMOND DH et al. Sexual transmission and the natural history of human herpesvirus 8 infection. N Engl J Med. 1998; 338(14): 948-954.

12. MARCELIN AG, ROQUE-AFONSO AM, HURBOVA M et al. Fatal disseminated Kaposi's sarcoma following human herpesvirus 8 primary infections in liver-transplant recipients. Liver Transpl. 2004; 10(2): 295-300.

13. Panel on Opportunistic Infections in Adults and Adolescents with HIV. Guidelines for the prevention and treatment of opportunistic infections in adults and adolescents with HIV: recommendations from the Centers for Disease Control and Prevention, the National Institutes of Health, and the HIV Medicine Association of the Infectious Diseases Society of America. Available at http://aidsinfo.nih.gov/contentfiles/lvguidelines/adult_oi.pdf. Accessed: 11 April 2020.

14. MARTIN JN. Kaposi sarcoma-associated herpesvirus/human herpesvirus 8 and Kaposi sarcoma. Adv Dent Res. 2011 ; 23 : 76-78.

15. BARESOVA P, PITHA PM, LUBYOVA B. Distinct roles of Kaposi's sarcoma-associated herpesvirus-encoded viral interferon regulatory factors in inflammatory response and cancer. J Virol. 2013; 87(17): 9398-9410.

16. MERCADER M, TADDEO B, PANELLA JR, et al. Induction of KSHV lytic cycle replication by inflammatory cytokines produced by HIV-1-infected T cells. Am J Pathol 2000; 156(6): 1961-71.

17. CAVALLIN LE, GOLDSCHMIDT-CLERMONT P, MESRI EA. Molecular and cellular mechanisms of KSHV oncogenesis of Kaposi's sarcoma associated with HIV/AIDS. PLoS Pathog. 2014; 10(7): e1004154.

18. WARREN-GASH C, FORBES HJ, WILLIAMSON E, et al. Human herpesvirus infections and dementia or mild cognitive impairment: a systematic review and meta-analysis. Sci Rep. 2019; 9(1): 4743.

19. NAGY S, GYULAI R, KEMENY L, et al. Iatrogenic Kaposi's sarcoma: HHV8 positivity persists but the tumors regress almost completely without immunosuppressive therapy. Transplantation 2000; 69:2230.

20. KIMBALL LE, CASPER C, KOELLE DM, et al. Reduced levels of neutralizing antibodies to Kaposi sarcoma-associated herpesvirus in persons with a history of Kaposi sarcoma. J Infect Dis 2004; 189: 2016.

21. MULAMA DH, MUTSVUNGUMA LZ, TOTONCHY J, et al. A multivalent Kaposi sarcoma-associated herpesvirus-like particle vaccine capable of eliciting high titers of neutralizing antibodies in immunized rabbits. Vaccine. 2019; 37(30): 4184-4194.

22. ARAMĂ V, STREINU CERCEL A. Infecții cu herpesvirusuri. Editura InfoMedica, București, 2002:439-466.

23. ANDREONI M, SARMATI L, NICASTRI E, et al. Primary Human Herpesvirus 8 Infection in Immunocompetent Children. JAMA. 2002; 287(10): 1295-1300.

24. LUPPI M, BAROZZI P, SCHULZ TF, SETTI G, STASKUS K, TROVATO R, NARNI F, et al. Bone marrow failure associated with human herpesvirus 8 infection after transplantation. N Engl J Med. 2000; 343: 1378-85.

25. WANG QJ, JENKINS FJ, JACOBSON LP, KINGSLEY LA, DAY RD, ZHANG ZW, et al. Primary human herpesvirus 8 infection generates a broadly specific CD8(+) T-cell response to viral lytic cycle proteins. Blood. 2001; 97: $2366-2373$.

26. REICHART PA, KHONGKHUNTHIAN P, BENDICK C. Oral manifestations in HIV-infected individuals from Thailand and Cambodia. Medical Microbiology and Immunology 2003; 192: 157-60.

27. FATAHZADEH M, SCHWARTZ RA. Oral Kaposi's sarcoma: a review and update. Int J Dermatol. 2013; 52: 666-672.

28. JELLIFFE DB, COOK J, DAVIES JN. Disseminated glandular Kaposi sarcoma in a Ugandan child. J Pediatr. 1962; 61: $452-5$.

29. DENIS D, SETA V, REGNIER-ROSENCHER E, KRAMKIMEL N, CHANAL J, AVRIL MF et al. A fifth subtype of Kaposi's sarcoma, classic Kaposi's sarcoma in men who have sex with men: a cohort study in Paris. J. Eur. Acad. Dermatol. Venereol. 2018; 32: $1377-1384$.

30. ISCOVICH J, BOFFETTA P, WINKELMANN R, BRENNAN P, AZIZI E, et al. Classic Kaposi's sarcoma in Jews living in Israel, 1961-1989: a population-based incidence study. AIDS. 1998; 12: 2067.

31. MAURER T, PONTE M, LESLIE K. HIV-associated Kaposi's sarcoma with a high CD4 count and a low viral load. N Engl J Med. 2007; 357: 1352-1353.

32. QUNIBI W, AKHTAR M, SHETH K, GINN HE, AL-FURAYH O, DEVOL EB, TAHER S, et al. Kaposi's sarcoma: the most common tumor after renal transplantation in Saudi Arabia. Am J Med. 1988; 84: 225-232.

33. WANG J, REID H, KLIMAS N, KOSHELEV M. An unusual series of patients with Kaposi sarcoma. JAAD Case Rep. 2019; 5(8): 646-649.

34. BIGI R, LANDIS JT, AN H, CARO-VEGAS C, RAAB-TRAUB N, DITTMER DP. Epstein-Barr virus enhances genome maintenance of Kaposi sarcoma-associated herpesvirus. Proc Natl Acad Sci U S A. 2018; 115(48): E11379-E11387.

35. BOWNE WB, LEWIS JJ, FILIPPA DA, NIESVIZKY R, BROOKS AD, BURT ME, et al. The management of unicentric and multicentric Castleman's disease: A report of 16 cases and a review of the literature. Cancer. 1999; 85(3): 706-17.

36. SOULIER J, GROLLET L, OKSENHENDLER E, CACOUB P, CAZALS-HATEM D, BABINET P, et al. Kaposi's sarcomaassociated herpesvirus-like DNA sequences in multicentric Castleman's disease. Blood. 1995; 86: 1276-1280. 
37. BOUVARD V, BAAN R, STRAIF K, GROSSE Y, SECRETAN B, GHISSASSI F, et al. A review of human carcinogens - part B: biological agents. Lancet Oncol. 2009; 10(4): 321-2.

38. INCANI A, MARRAS L, SERRELI G, INGIANNI A, POMPEI R, DEIANA M, et al. Human Herpesvirus 8 infection may contribute to oxidative stress in diabetes type 2 patients. BMC Res Notes. 2020; 13: 75.

39. MANNERS O, MURPHY JC, COLEMAN A, HUGHES DJ, WHITEHOUSE A. Contribution of the KSHV and EBV lytic cycles to tumourigenesis. Curr Opin Virol. 2018; 32: 60-70.

40. CHEN J, DAI L, GOLDSTEIN A, ZHANG H, TANG W, FORREST C, et al. Identification of new antiviral agents against Kaposi's sarcoma-associated herpesvirus (KSHV) by high-throughput drug screening reveals the role of histamine-related signaling in promoting viral lytic reactivation. PLoS Pathog. 2019; 15(12): e1008156.

41. STEBBING J, PORTSMOUTH S, GAZZARD B. How does HAART lead to the resolution of Kaposi's sarcoma? J Antimicrob Chemother. 2003; 51: 1095-1098.

42. LEBBE C, GARBE C, STRATIGOS AJ, GROB JJ, PAGES C. Diagnosis and treatment of Kaposi's sarcoma: European consensusbased interdisciplinary guideline (EDF/EADO/EORTC). Eur J Cancer. 2019; 114: 117-27.

43. CHAN K, LADE S, PRINCE H, HARRISON S. Update and new approaches in the treatment of Castleman disease. J Blood Med. 2016; 7: 145-158.

Received $10^{\text {th }}$ June 2020 